\title{
Glyoxal Damages Human Aortic Endothelial Cells by Perturbing the Glutathione, Mitochondrial Membrane Potential, and Mitogen-Activated Protein Kinase Pathways
}

\section{Ming-Zhang Xie}

First Affiliated Hospital of Xinxiang Medical University

Chun Guo

First Affiliated Hospital of Xinxiang Medical University

Jia-Qi Dong. BA

First Affiliated Hospital of Xinxiang Medical University

Jie Zhang

First Affiliated Hospital of Xinxiang Medical University

Ke-Tao Sun

Central Hospital of Zibo

Guang-Jian Lu

First Affiliated Hospital of Xinxiang Medical University

Lei Wang

First Affiliated Hospital of Xinxiang Medical University

De-Ying Bo

First Affiliated Hospital of Xinxiang Medical University

Guo-An Zhao ( $\square$ Tougao3@sohu.com )

First Affiliated Hospital of Xinxiang Medical University

Lu-Yang Jiao

First Affiliated Hospital of Xinxiang Medical University

\section{Research Article}

Keywords: C ardiovas cular diseases, Human aortic endothelial cells, Mitogen activated protein kinase pathways, Glyoxal , Laboratory indexes

Posted Date: March 11th, 2021

DOl: https://doi.org/10.21203/rs.3.rs-270505/v1 
License: (c) (i) This work is licensed under a Creative Commons Attribution 4.0 International License. Read Full License

Version of Record: A version of this preprint was published at BMC Cardiovascular Disorders on December 1st, 2021. See the published version at https://doi.org/10.1186/s12872-021-02418-3. 


\section{Glyoxal Damages Human Aortic Endothelial Cells by Perturbing the}

2 Glutathione, Mitochondrial Membrane Potential, and Mitogen-Activated Protein

3 Kinase Pathways

4 Ming-Zhang Xie, Ph.D." , a Chun Guo, Ph.D. ${ }^{\text {, }}$, Jia-Qi Dong. BA ${ }^{\text {c }}$, Jie Zhang, BA ${ }^{\text {d }}$, Ke-Tao Sun, BA ${ }^{\text {e }}$

5 Guang-Jian Lu, MD ${ }^{\text {a }}$, Lei Wang, MD ${ }^{\text {a }}$, De-Ying Bo, MD a,Guo-An Zhao, Ph.D. * c, Lu-Yang Jiao BA *,

$7 \quad{ }^{a}$ Department of Laboratory, First Affiliated Hospital of Xinxiang Medical University, Xinxiang, Henan

$8 \quad$ PR, 453000, China

$9 \quad \mathrm{~b}$ Henan Key Laboratory of Neural Regeneration (Henan Joint International Research Laboratory of

10 Neurorestoratology for Senile Dementia), First Affiliated Hospital of Xinxiang Medical University,

11 Xinxiang, Henan PR, 453000, China

$12{ }^{c}$ Department of Cardiovascular, First Affiliated Hospital of Xinxiang Medical University, Xinxiang,

13 Henan PR, 453000, China

$14{ }^{\mathrm{d}}$ Department of Integrating Western and Chinese of Internal Medicine, First Affiliated Hospital of

15 Xinxiang Medical University, Xinxiang, Henan PR, 453000, China

16 e Department of Laboratory, Zibo Central Hospital, Zibo, Shandong PR, 255036, China

$17 *$ These authors are equal contributors to this work.

18 Corresponding authors:

19 Ming-Zhang Xie

20 Department of Laboratory, First Affiliated Hospital of Xinxiang Medical University, Xinxiang, Henan

21 PR, 453000, China

22 Email: 77128425@qq.com. Telephone: +8616627700932 
Guo-An Zhao

Department of Cardiovascular, The First Affiliated Hospital of Xinxiang Medical University, Xin

Xiang, 453003, China.

Email: tougao3@sohu.com. Telephone: +86 15537325493

Lu-Yang Jiao

Department of Laboratory, First Affiliated Hospital of Xinxiang Medical University, 453000, Xinxiang,

Henan PR, China

Email: jly@xxmu.edu.cn. Telephone: +86 15837325993

word count: 4948 , figures: 5

\section{Abstract}

Background: Exposure to glyoxal, the smallest dialdehyde, is associated with several diseases; humans are routinely exposed to glyoxal because of its ubiquitous presence in foods and the environment. The aim of this study was to examine the damage caused by glyoxal in human aortic endothelial cells.

Methods: Cell survival assays and quantitative fluorescence assays were performed to measure DNA damage; oxidative stress was detected by colorimetric assays and quantitative fluorescence, and the mitogen-activated protein kinase pathways were 
assessed using western blotting.

Results: Exposure to glyoxal was found to be linked to abnormal glutathione activity, the collapse of mitochondrial membrane potential, and the activation of mitogen-activated protein kinase pathways. However, DNA damage and thioredoxin oxidation were not induced by dialdehydes.

Conclusions: Intracellular glutathione, members of the mitogen-activated protein kinase pathways, and the mitochondrial membrane potential are all critical targets of glyoxal. These findings provide novel insights into the molecular mechanisms perturbed by glyoxal and may facilitate the development of new therapeutics and diagnostic markers for cardiovascular diseases.

Keywords: Cardiovascular diseases, Human aortic endothelial cells, Mitogen-activated protein kinase pathways, Glyoxal, Laboratory indexes

\section{Introduction}

Glyoxal (GX), the smallest dialdehyde, is the most widely used retarding agent in the synthesis of chemicals, such as novel bio-adhesives for wood [1-3], or those from the environment [4]. In humans, a high dietary glycemic load leading to insulin resistance causes alterations in glucose and lipid metabolism, leading to production of excess aldehydes, including GX and methylglyoxal, which are associated with the progression of certain diseases, including cardiovascular disorders [5, 6]. With respect to tissue dysfunction, GX has been implicated in the progression of several degenerative conditions, such as Alzheimer's disease and diabetes mellitus, in which increased serotonin release from cells might stimulate serotonin-mediated intestinal 
motility [7]. Furthermore, the consumption of high-carbohydrate diets might also induce the endogenous formation of GX [6]. Regarding DNA damage and tumor growth, DNA duplexes can undergo intra- and inter-cross-linking damage through the formation of GX-guanine adducts $[8,9]$. Exposure to $0.1 \% \mathrm{GX}$ was found to cause a significant increase in tumor size in the small intestines of male and female mice [10]. GX can also trigger changes to erythrocytes. Specifically, it induces the modification of arginine residues of $\mathrm{HbA} 0$-forming $\mathrm{G}-\mathrm{H} 1$, which decreases free iron-mediated oxidative reactions. GX-derived G-H1-mediated changes in the structural and functional properties of the heme protein, observed in vivo, may be of clinical significance [11]. Erythrocytes take up exogenous GX and convert it primarily to glycolate, and approximately $1 \%$ is converted to oxalate. This pathway of oxalate formation may be enhanced in diabetes and other diseases associated with increased oxidative stress [12]. Glutathione (GSH), a reactive Cys residue containing a tripeptide, is the major soluble antioxidant molecule in cells due to its abundance in the cytosol, nucleus, and mitochondrion [13-16]. Thioredoxin-1(Trx1) mainly acts by cleaving the disulfide bonds of oxidized proteins, thus affecting intracellular scavenging of oxidative stress. This action relies on cell survival, cell growth, and gene transcription. [17]. Finally, the enzymes involved in glycolysis are heavily modified by GX, which can significantly inhibit the activity of GAPDH, which in turn may contribute to the pathological processes by impairing glycolytic processes [18].

The toxic effects of aldehydes include protein damage caused by the exposure of cells to endogenous and exogenous aldehydes, which leads to the formation of covalent adducts with proteins, causing dysfunction. In addition, DNA damage such as DNA double strand breaks (DSBs) [19], DNA-protein crosslinks (DPCs), or DNA interstrand crosslinks (ICLs), [20] occurs when a protein or DNA base in one strand undergoes further reactions with aldehyde-DNA base adducts in the opposite strand [21]. The FANC pathway, which includes the complementation group A (FANCA), is 
the major mechanism underlying the repair of ICLs induced by aldehydes [19].

Previous studies have shown that aldehydes [17-19] are independent risk factors for cardiovascular disease. For example, GX is associated with critical targets in the human aortic endothelial cells (HAECs), which are implicated in several cardiovascular diseases. GX is also involved in the development of abnormal structures and functions of the arteries, such as atherosclerosis [5-6]. The main objective of this study was to examine the damage-inducing effects of GX on HAECs and to provide novel insights into the molecular mechanisms that are perturbed by GX, which may, in turn, facilitate the development of new therapeutics and diagnostic markers for cardiovascular diseases.

\section{Materials and Methods}

\subsection{Chemicals}

Buthionine sulfoximine (BSO), iodoacetic acid (IAA), iodoacetamide (IAM), auranofin (Auro), and carbonyl cyanide $m$-chlorophenylhydrazone (CCCP) were purchased from Solarbio (Beijing, China); CCCP and Auro were solubilized in dimethyl sulfoxide (DMSO) before use. GX (40\%, v/v) was obtained from Xiya Chemical Industry (Jinan, China) and was dissolved in MilliQ water (Massachusetts,USA) before use. HAECs were purchased from Bena Culture Collection Co. (Beijing, China). Fanconi anemia complementation group A (FANCA) siRNA and siRNA-mate were purchased from GenePharma Co., Ltd. (Shanghai, 
China). The GSH peroxidase assay kit was obtained from the Nanjing Jiancheng Bioengineering Institute (Nanjing, China). Trx1, phospho extracellular signal regulated kinase (P-ERK), phospho c-Jun N-terminal kinase (P-JNK), and phospho p38 kinase (P-P38) antibodies were purchased from Abcam (Cambridge, UK), and Enhanced chemiluminescence (ECL) western blotting substrate was obtained from Biosharp (Hefei, China). The mitochondrial membrane potential kit was purchased from Abbkine (California, USA), fetal bovine serum was obtained from Tianhang (Zhejiang,China)

\section{2. siRNA Knockdown of FANCA}

FANCA siRNA and siRNA-mate were mixed for $10 \mathrm{~min}$ at room temperature to form siRNA-liposome complexes and were transfected into HAECs to inhibit the expression of FANCA. HAECs were maintained in Dulbecco's modified Eagle's medium with $10 \%$ inactivated fetal bovine serum (FBS) in a $5 \% \mathrm{CO}_{2}$ atmosphere at $37^{\circ} \mathrm{C}$ in a humidified incubator for $48-96 \mathrm{~h}$, followed by harvesting of lysates for western blot analyses.

\subsection{Cell Culture and Survival Assays}

HAECs were cultured as described previously. For the survival assays with GX, 12 $\mathrm{h}$ after plating of the cells, the medium was replaced with fresh medium containing a 
range of indicated concentrations of $\operatorname{GX}(0,50,100,150$, and $200 \mu \mathrm{M})$ every day, and cells were incubated for 8 days to form colonies. For survival assays, BSO, which can specifically inhibit $\gamma$-glutamylcysteine synthetase, was used to deplete the intracellular GSH concentration. HAECs were incubated in culture medium with $1 \mathrm{mM}$ BSO for up to $72 \mathrm{~h}$. Auro is an inhibitor of thioredoxin reductase, which specifically interferes with the reduction of oxidized $\operatorname{Trx} 1$ and was applied at a concentration of $0-6 \mu \mathrm{M}$ for $24 \mathrm{~h}$, while HAEC membrane permeability to protons was augmented with CCCP treatment $(0-800 \mu \mathrm{M}$ for $2 \mathrm{~h})$.

HAECs were rinsed twice with PBS after treatment; then, the cells were incubated in fresh medium for 8 days to form colonies. Only colonies with more than 50 cells were counted. Drug lethal dose $\left(\mathrm{LD}_{90}\right)$ values were determined based on the GX dose that produced $90 \%$ cell damage, as confirmed from survival curves.

\subsection{Measurement of GSH Levels}

To determine the critical targets of GX, we assessed the changes in the intracellular GSH level. HAECs were treated with GX (LD90). Untreated cells were used as the negative control group. Using a GSH detection kit, GSH was measured immediately after treatment.

The biochemical principle of this protocol is that dithionitrobenzoic acid reacts with sulfhydryl compounds, resulting in a yellowish coloration of the compounds, a process which is catalyzed by GSH. Briefly, HAECs $\left(1 \times 10^{6}\right)$ were suspended and lysed by ultrasound after treatment with GX (LD90, $0.12 \mathrm{mM}$, for 8 days) or BSO. The 
samples were mixed with GSH $(1 \mathrm{mM})$ and reagent 1 and incubated at $37^{\circ} \mathrm{C}$ for $5 \mathrm{~min}$. This was followed by adding a reaction mixture of reagents $2-5$ to the samples and incubating at $37^{\circ} \mathrm{C}$ for $15 \mathrm{~min}$. Results were measured using an absorbance microplate reader (420 nm; Molecular Devices; California, USA).

\subsection{Measurement of the Redox State of Trx1}

The samples with reduced and oxidized cysteine thiol groups were treated with GX, Trx1 proteins bearing different charges were separated by urea-polyacrylamide gel electrophoresis (PAGE) and selectively detected by western blotting [22]

Preparation of Electrophoretic Migration Markers: All cysteine residues were reduced by incubating HAECs with $3.5 \mathrm{mM}$ dithiothreitol (DTT) in urea buffer (8 M urea, $100 \mathrm{mM}$ tris- $\mathrm{HCl}[\mathrm{pH} \quad 8.2]$, and $1 \mathrm{mM}$ EDTA) for $30 \mathrm{~min}$ at $37^{\circ} \mathrm{C}$. Electrophoretic migration markers were treated with $15 \mathrm{mM} \mathrm{IAA}+15 \mathrm{mM}$ IAM for alkylation at $37^{\circ} \mathrm{C}$ for $15 \mathrm{~min}$.

Preparation of the Trx1 Proteins with an Unknown Redox State. After treatment with GX ( $\mathrm{LD}_{90}, 0.12 \mathrm{mM}$, for 8 days) or Auro, the Trx1 proteins were alkylated with $200 \mu \mathrm{L}$ of urea buffer ( $30 \mathrm{mM}$ IAA) for $15 \mathrm{~min}$ at $37^{\circ} \mathrm{C}$. Two milliliters of acetone- 1 $\mathrm{N} \mathrm{HCl}\left(4^{\circ} \mathrm{C}, 98: 2 \mathrm{v} / \mathrm{v}\right)$ was used to precipitate proteins, and unreacted IAA was removed by microcentrifugation for $5 \mathrm{~min}$ at $11,000 \mathrm{~g}$ at $4^{\circ} \mathrm{C}$. The pellet was resuspended and washed in acetone $-1 \mathrm{~N} \mathrm{HCl}-\mathrm{H}_{2} \mathrm{O}\left(4^{\circ} \mathrm{C}, 98: 2: 10 \mathrm{v} / \mathrm{v} / \mathrm{v}\right)$ three times by microcentrifugation for $5 \mathrm{~min}$ at $11,000 \mathrm{~g}$ at $4^{\circ} \mathrm{C}$. TRX1 proteins were then 
reduced by incubating them with $200 \mu \mathrm{L}$ of urea buffer containing $3.5 \mathrm{mM}$ DTT for $30 \mathrm{~min}$ at $37^{\circ} \mathrm{C}$. $\quad \operatorname{Trx} 1$ proteins were mixed with $10 \mathrm{mM}$ IAM for $15 \mathrm{~min}$ at $37^{\circ} \mathrm{C}$.

$$
\text { Detection of the Redox State of } \operatorname{Trx} 1 \text {. The treated } \operatorname{Trx} 1 \text { samples and the }
$$
electrophoretic migration markers were analyzed with an $8 \mathrm{M}$ urea-PAGE gel, using a $2.5 \%$ stacking gel and $12 \%$ separating gel run at a constant current of $5 \mathrm{~mA}$ for $3.5 \mathrm{~h}$. Proteins were transferred to a polyvinylidene fluoride (PVDF) membrane (Darmstadt,DE) after electrophoresis and incubated at $4{ }^{\circ} \mathrm{C}$ for $24 \mathrm{~h}$ in TBST (20 mM tris- $\mathrm{HCl}$ [pH 7.6], $140 \mathrm{mM} \mathrm{NaCl}$ and $0.1 \%$ tween). The membranes were probed with the relevant primary antibody (ABCAM, ab109385, 1:20000) at $4^{\circ} \mathrm{C}$ overnight, followed by three rinses with TBST. They were then incubated with the enzyme-labeled goat anti-rabbit $\operatorname{IgG}(1: 5000)$ at $37^{\circ} \mathrm{C}$ for $2 \mathrm{~h}$. The membrane was incubated with the ECL western blotting substrate after washing with TBST. Chemiluminescence was quantified on a ChemiDoc XRS + system (Bio-Rad (California, USA), and results were determined using Image $1.47 \mathrm{v}$.

\subsection{Measurement of the Mitochondrial Membrane Potential}

To determine critical GX targets, we determined the effect of GX on mitochondrial function. HAECs were treated with GX (LD90, $0.12 \mathrm{mM}$, for 8 days) or without GX (control) and subsequently assessed using a mitochondrial membrane potential assay kit. The measurements were taken immediately after treatment. Briefly, cells were washed and seeded onto a 96-well plate with $100 \mu \mathrm{L}$ buffer/well. After 
treatment with GX (LD90) or CCCP, a working solution of the carbocyanine dye JC-1 (100 $\mu \mathrm{L} /$ well) was added, followed by incubation in the dark at $37^{\circ} \mathrm{C}$ for $10 \mathrm{~min}$. Results were measured on a Hitachi F-2500 fluorescence spectrophotometer (Tokyo, JPN) at $\lambda$ ex $=529 \mathrm{~nm}$ and $\lambda \mathrm{em}=590 \mathrm{~nm}$.

\subsection{Western Blotting}

HAECs were washed with PBS and then harvested for treatment with the protein inhibitor (Hefei, China); $30 \mu \mathrm{g}$ of proteins were subjected to separation on a $10 \%$ resolving sodium dodecyl sulfate-polyacrylamide gel electrophoresis (SDS-PAGE) gel. The separated proteins were then transferred onto PVDF membranes using a blotting instrument (Bio-Rad (California, USA)). The samples were incubated with the relevant primary antibody at $4{ }^{\circ} \mathrm{C}$ overnight, after which they were blocked with $5 \%$ bovine serum albumin (20 mM tris- $\mathrm{HCl}$ [pH 7.6], $140 \mathrm{mM} \mathrm{NaCl}$ and $0.1 \%$ Tween ) for $2 \mathrm{~h}$ at $37^{\circ} \mathrm{C}$. The steps thereafter were the same as those mentioned in section 2.5.3 after incubation with the primary antibody.

\subsection{Measurement of DPCs}

HAECs were treated with GX (LD90, $0.12 \mathrm{mM}$, for 8 days) and without GX (control) to measure DPCs [23]. Briefly, cells were processed with sarkosyl, mixed with $9.3 \mathrm{~g}$ of $\mathrm{CsCl}\left(\right.$ Wako,JPN) and sedimented at $500000 \times \mathrm{g}$ at $20^{\circ} \mathrm{C}$ for $4 \mathrm{~h}(\mathrm{CsCl}$ 
density gradient centrifugation) to isolate chromosomal DNA. Fluorescein isothiocyanate was dissolved in dimethylformamide to a final concentration of 0.1 $\mathrm{mM}$ to label DPCs. DPCs were measured with a Hitachi F-2500 fluorescence spectrophotometer(Hitachi, JPN) $(\lambda$ ex $=490 \mathrm{~nm}, \lambda$ em $=520 \mathrm{~nm})$.

2.9 Measurement of DSBs

HAECs were irradiated with X-rays (marker), with GX (LD90, $0.12 \mathrm{mM}$, for 8 days) or no GX (control), after which DSBs [19] were detected by static-field gel electrophoresis. Cells $\left(10^{4}\right)$ were loaded on plug molds, and the plugs were slid into $0.6 \%$ SeaKem gold agarose gels; electrophoresis was performed for $36 \mathrm{~h}$ at a field strength of $0.6 \mathrm{~V} \mathrm{~cm}$ in $0.5 \times \mathrm{TBE}$ buffer to isolate DSBs. The samples were detected with a UV transilluminator and captured using a digital camera (Bio-Rad (California, USA)). The band intensity was subsequently determined using ImageJ software 242 (version 1.47).

\subsection{Statistical Analysis}

Data are presented as mean \pm standard deviation of results from three to five repetitions. Statistical analysis was performed using the SPSS 22 package. $T$-test was used to evaluate the statistical differences for paired data.

\section{Results}


3.1 DNA Repair is Not Important in Attenuating GX Toxicity

ICLs are amongst the most serious types of DNA damage induced by aldehydes $[24,25]$. To determine whether GX generates ICLs in HAECs, cells were exposed to GX in the culture medium to determine the tolerance mechanism to DNA damage. HAECs deficient in the FANC pathway $\left(\mathrm{LD}_{90}=0.15 \mathrm{mM}\right)$ were insensitive to $\mathrm{GX}$ in comparison with HAECs that were confirmed to be positive for the FANC pathway $\left(\mathrm{LD}_{90}=0.12 \mathrm{mM}\right)\left(\right.$ Fig. 1A). Upon treating HAECs with $\mathrm{GX}\left(\mathrm{LD}_{90}, 0.12 \mathrm{mM}\right.$, for 8 days), the DPC (Fig. 1C) and DSB (Fig. 1B) results were similar to those in the negative control group ( $\mathrm{p}>0.05)$. Thus, we concluded that DPCs, ICLs, and DSBs were not the primary reasons for DNA damage (Fig. 1B and 1C).

\subsection{GX Partially Inactivates HAECs Via Disruption of GSH}

Intracellular GSH levels decreased after treatment with GX (55\% relative to the negative control group), as well as BSO (62\% relative to untreated control cells; Fig. 2A). BSO induced moderate damage (60\% survival) as observed by evaluation with clonogenic assays (Fig. 2B). Thus, our results show that depletion of GSH occurs in the presence of GX, which contributes to cytotoxicity in HAECs.

\subsection{Depletion of Mitochondrial Membrane Potential Causes Moderate Cytotoxicity}



respect to protons; the cells showed decreased mitochondrial membrane potential $(58 \%$ relative to that in negative control cells) compared to that with GX treatment (55\% relative to that in the untreated control cells; Fig. 3A). CCCP induced HAEC damage disruption of the mitochondrial membrane potential is an important reason for cell damage.

\subsection{Oxidation of Trx1 Causes Moderate Cytotoxicity}

$\operatorname{Trx} 1$ is a thiol protein and critical regulator of the redox state balance. To determine critical GX targets, we assessed the effect of GX on the oxidation of Trx1. HAECs were treated with $\mathrm{GX}\left(\mathrm{LD}_{90}\right)$ and without $\mathrm{GX}$ (control) to induce different charges, which were measured immediately. The resulting modified proteins were separated by urea-PAGE and measured by western blotting. According to the different redox states, several distinct bands were separated (Fig. 4A). An upper shift of bands was observed immediately after treatment with GX (LD90; GX band $=1.87$ relative to that in the untreated control cells Fig. 4A). Auro is an inhibitor of thioredoxin reductase, which interferes with the reduction of oxidized Trx1, thus resulting in an upper shift of bands (Auro band $=3.29$ relative to that in untreated control cells). Thus, the rates of oxidized Trx 1 with GX treatment changed compared to those in the untreated control cells. The results showed a dramatic decrease in cell survival (32\% survival) after the 
treatment with Auro when analyzed by the clonogenic assay (Fig. 4B). Thus, oxidized Trx 1 that was subjected to interference by GX showed moderate cytotoxicity.

3.5 Activation of Mitogen-activated Protein (MAP) Kinase Pathways, including P-ERK, P-JNK, and P-P38

HAECs were incubated with GX in culture medium to determine its effect on the MAP kinase pathways. HAECs were treated with GX (LD90) and without GX (control), and then effects were measured immediately. Results showed that activation levels of the MAP kinase pathway members increased immediately after treatment with GX, including P-ERK (105\%), P-JNK (314\%), and P-P38 (159\%) in comparison to control levels (Fig. 5).

\section{Discussion}

As an important pollutant, endogenous GX can be produced by the metabolism of carbohydrates and oxidation of lipids or nucleic acids, whereas exogenous GX is present in foods and is released to the environment through activities such as smoking $[26,27]$. Aldehydes differ in their reactivity and damaging effects in HAECs due to their different chemical structures $[24,28]$. However, to our knowledge, no study has shown the targets of critical damage in HAECs or the mechanism of protein damage resulting from GX cytotoxicity in conjunction with that of DNA damage, because concurrent DNA damage by dialdehydes yields similar results [24, 29]. 
ICLs constitute the most serious of the DNA damage types induced by aldehydes. The primary mechanism of ICL damage repair induced by aldehydes is the FANC pathway $[24,25]$. Previous research has shown that ICLs, but not DPCs and DSBs, cause the critical cytotoxicity mediated by monoaldehydes [24, 25].This study explored the effects of DNA damage-induced cytotoxicity by a dialdehyde (GX). We found that the FANC repair-deficient pathway is not essential for cell survival by mitigating the cytotoxicity of GX. The DPCs, ICLs, and DSBs were also not the were confirmed in a previous study, which correlated these with type 2 diabetes mellitus [8]. The differences in results from those of HAECs could be attributed to the use of different cell types. Our results differ from the results of studies on monoaldehydes as dialdehydes and monoaldehydes are completely different in their chemical structures $[24,30]$. To the best of our knowledge, this is the first study to report such a relationship between DNA damage and the pathologically significant induction of cardiovascular disease by dialdehydes. anti-decrepitude and in liver protection, free radical scavenging, cancer treatment, and incretion maladjustment in clinic [13-15]. We therefore sought to determine the effect of intracellular GSH depletion and the collapse of mitochondrial membrane potential. Our results showed that the major cytotoxic mechanism by which GX induced cardiovascular disease includes the depletion of intracellular GSH and the collapse of mitochondrial membrane potential. Previous research has shown that GX induces 
oxidative stress in different diseases, such as diabetic mellitus [31]. These results are also similar to the results of studies performed on monoaldehydes [24, 29, 31].

Endogenous antioxidant pathways, such as Trx1, protect from an increase in oxidative stress. Trx1 has been reported as a cornerstone in maintaining the cellular redox status and regulation of signaling mechanisms [17, 32]. We also identified the role of oxidized Trx1 in inducing cardiovascular disease mediated by GX, by using a modified western blot analysis. GX-mediated reduction of oxidized Trx1 resulted in partial HAEC cytotoxicity. To the best of our knowledge, this is the first report to directly assess the reduction of oxidized Trx 1 in HAECs using the modified western blot analysis. Similar results have indicated that dialdehydes (methylglyoxal) can assist glyoxalase and $\operatorname{Trx} 1$ at low concentrations but have an opposite effect at high concentrations [33]. Chemical modification of Trx1 by monoaldehydes can contribute to the development of cardiovascular disease by interfering with the redox signaling functions of $\operatorname{Trx} 1[24,33]$. However, the underlying reason needs to be elucidated in further research.

We also determined the effect of GX on the activation of MAP kinase pathways using western blot analysis and determined that they indeed contain critical targets, including P-ERK, P-JNK, and P-P38 MAPK, in HAECs. Previous studies have shown that P-JNK and P-ERK induce human cell apoptosis [34, 35]. To the best of our knowledge, this is the first study to directly assess the relationship between HAEC apoptosis and the activation of MAP kinase pathways induced by GX.

In short, the critical effects of GX include the depletion of intracellular GSH, 
activation of MAP kinase pathways, and collapse of the mitochondrial membrane potential. Oxidative stress induces the depletion of intracellular GSH, and suppression of the p38 MAPK signaling pathway can alleviate oxidative stress [36]. P-P38 MAPK can induce oxidative stress and apoptosis in human lens epithelial cells [37]. Thus, previous studies have shown that these critical targets affected each other to damage HAECs.

\section{Summary and Conclusions}

GX is a serious pollutant that humans are extensively exposed to, and it is subsequently a major factor underlying cardiovascular disorders. However, thus far, the molecular mechanisms underlying this action of GX have remained unknown.

374 This study shows that critical targets include the depletion of intracellular GSH, 375 activation of MAP kinase pathways and collapse of mitochondrial membrane 376 potential, also showing that DNA repair is not important in attenuating GX toxicity.

377 The present findings provide novel insights into the understanding of these molecular 378 mechanisms and may help in the development of new therapeutic targets and 379 diagnostic markers in cardiovascular disease, as well as to provide a reference for the 380 progression of precision medicine.

\section{Declaration}




\section{Acknowledgements}

385

We would like to thank Editage for English language editing.

Ethics Approval

N/A

390

\section{Consent to Participate}

N/A

Consent to publication

N/A

\section{Data Availability Statement}

397

398

The data used to support the findings of this study are available from the corresponding author upon request.

400

401

\section{Author Contributions}

402

L-Y J, M-Z X, and G-A Z conceived and designed the study.

403

M-Z X, C-G, J-Z, J-Q D, G-J L performed the experiments.

404

M-Z X and C-G wrote the paper.

405

M-Z X, C-G, L-Y J and G-A Z reviewed and edited the manuscript. 
analysis, or interpretation of data for the work; (2) participated in drafting the work or revising it critically for important intellectual content; (3) approved the final version of the manuscript; and (4) agreed to be accountable for all aspects of the work in ensuring that questions related to the accuracy or integrity of any part of the work are appropriately investigated and resolved

\section{Author details}

Ming-Zhang Xie, Ph.D.", a Chun Guo, Ph.D. ${ }^{\mathrm{b}}$, Jia-Qi Dong. BA ${ }^{\mathrm{c}}$, Jie Zhang, BA ${ }^{\mathrm{d}}$, Ke-Tao Sun, BA ${ }^{\mathrm{e}}$,

${ }^{\mathrm{b}}$ Henan Key Laboratory of Neural Regeneration (Henan Joint International Research Laboratory of

${ }^{\mathrm{c}}$ Department of Cardiovascular, First Affiliated Hospital of Xinxiang Medical University, Xinxiang,

${ }^{d}$ Department of Integrating Western and Chinese of Internal Medicine, First Affiliated Hospital of 
Guo-An Zhao

Department of Cardiovascular, The First Affiliated Hospital of Xinxiang Medical University, Xin

Email: tougao3@sohu.com. Telephone: +86 15537325493

\section{Disclosure Statement}

The authors have no conflicts of interest to report.

\section{Funding}

451 This study was supported by key scientific and technological research projects of 


\section{References}

1. Hazwan Hussin M, Aziz AA, Iqbal A, Ibrahim MNM, Latif NHA: Development and characterization novel bio-adhesive for wood using kenaf core (Hibiscus cannabinus) lignin and glyoxal. International journal of biological macromolecules 2019, 122:713-722.

2. Hazwan Hussin M, Samad NA, Latif NHA, Rozuli NA, Yusoff SB, Gambier F, Brosse N: Production of oil palm (Elaeis guineensis) fronds lignin-derived non-toxic aldehyde for eco-friendly wood adhesive. International journal of biological macromolecules 2018, 113:1266-1272.

3. Ho SS, Ip HS, Ho KF, Ng LP, Chan CS, Dai WT, Cao Jj: Hazardous airborne carbonyls emissions in industrial workplaces in China. Journal of the Air \& Waste Management Association (1995) 2013, 63(7):864-877.

4. Zarzana KJ, Min KE, Washenfelder RA, Kaiser J, Krawiec-Thayer M, Peischl J, Neuman JA, Nowak JB: Emissions of Glyoxal and Other Carbonyl Compounds from Agricultural Biomass Burning Plumes Sampled by Aircraft. 2017, 51(20):11761-11770.

5. Vasdev S, Gill V, Singal P: Role of advanced glycation end products in hypertension and atherosclerosis: therapeutic implications. Cell biochemistry and biophysics 2007, 49(1):48-63.

6. Maasen K, van Greevenbroek MMJ, Scheijen J, van der Kallen CJH, Stehouwer CDA, Schalkwijk CG: High dietary glycemic load is associated with higher concentrations of urinary advanced glycation endproducts: the Cohort on Diabetes and Atherosclerosis Maastricht (CODAM) Study. The American journal of clinical nutrition 2019, 110(2):358-366.

7. Holik AK, Lieder B, Kretschy N, Somoza MM, Ley JP, Hans J, Somoza V: The advanced glycation end product $N(\epsilon)$-carboxymethyllysine and its precursor glyoxal increase serotonin release from Caco-2 cells. 2018, 119(3):2731-2741.

8. Vilanova B, Fernández D, Casasnovas R, Pomar AM, Alvarez-Idaboy JR, Hernández-Haro N, Grand A, Adrover M, Donoso J, Frau J et al: Formation mechanism of glyoxal-DNA adduct, a DNA cross-link precursor. International journal of biological macromolecules 2017, 98:664-675.

9. Nevin C, McNeil L, Ahmed N, Murgatroyd C, Brison D, Carroll M: Investigating the Glycating Effects of Glucose, Glyoxal and Methylglyoxal on Human Sperm. Sci Rep 2018, 8(1):9002. 
10. Svendsen $\mathrm{C}$, Høie AH, Alexander J, Murkovic M, Husøy $\mathrm{T}$ : The food processing contaminant glyoxal promotes tumour growth in the multiple intestinal neoplasia (Min) mouse model. Food and chemical toxicology : an international journal published for the British Industrial Biological Research Association 2016, 94:197-202.

11. Banerjee S: Glyoxal-induced modification enhances stability of hemoglobin and lowers iron-mediated oxidation reactions of the heme protein: An in vitro study. International journal of biological macromolecules 2018, 107(Pt A):494-501.

12. Knight J, Wood KD, Lange JN, Assimos DG, Holmes RP: Oxalate Formation From Glyoxal in Erythrocytes. Urology 2016, 88:226.e211-225.

13. Antioxidant effects of an olive oil total polyphenolic fraction from a Greek Olea europaea variety in different cell cultures. Phytomedicine International Journal of Phytotherapy \& Phytopharmacology 2018.

14. Paraskevi, Kouka, Alexandros, Priftis, Dimitrios, Stagos, Apostolis, Angelis, Panagiotis, Stathopoulos: Assessment of the antioxidant activity of an olive oil total polyphenolic fraction and hydroxytyrosol from a Greek Olea?europea variety in endothelial cells and myoblasts. International Journal of Molecular Medicine 2017.

15. Veskoukis AS, Kerasioti E, Priftis A, Kouka P, Spanidis Y, Makri S, Kouretas D: A battery of translational biomarkers for the assessment of the in vitro and in vivo antioxidant action of plant polyphenolic compounds: the biomarker issue. Current Opinion in Toxicology 2018.

16. Valko M, Leibfritz D, Moncol J, Cronin MT, Mazur M, Telser J: Free radicals and antioxidants in normal physiological functions and human disease. The international journal of biochemistry \& cell biology 2007, 39(1):44-84.

17. Dagnell M, Cheng Q, Arnér ESJ: Qualitative Differences in Protection of PTP1B Activity by the Reductive Trx1 or TRP14 Enzyme Systems upon Oxidative Challenges with Polysulfides or H2O2 Together with Bicarbonate. Antioxidants 2021, 10(1):111.

18. Chen Y, Qin W, Li Z, Guo Z, Liu Y, Lan T, Wang C: Site-specific chemoproteomic profiling of targets of glyoxal. 2019, 11(23):2979-2987.

19. Xie MZ, Shoulkamy MI, Salem AM, Oba S, Goda M, Nakano T, Ide H: Aldehydes with high and low toxicities inactivate cells by damaging distinct cellular targets. Mutation research 2016, 786:41-51.

20. Kitao H, Takata M: Fanconi anemia: a disorder defective in the DNA damage response. International Journal of Hematology 2011, 93(4):417-424.

21. Chen HC, Chang YL, Teng YC, Hsiao CF, Lin TS: A Stable Isotope Dilution Nanoflow Liquid Chromatography Tandem Mass Spectrometry Assay for the Simultaneous Detection and Quantification of Glyoxal-Induced DNA Cross-Linked Adducts in Leukocytes from Diabetic Patients. Analytical chemistry 2017, 89(24):13082-13088.

22. Bersani NA, Merwin JR, Lopez NI, Pearson GD, Merrill GF: Protein electrophoretic mobility shift assay to monitor redox state of thioredoxin in cells. Methods in Enzymology 2002, 347(1):317.

23. Shoulkamy MI, Nakano T, Ohshima M, Hirayama R, Uzawa A, Furusawa Y, Ide H: Detection of DNA-protein crosslinks (DPCs) by novel direct fluorescence labeling methods: distinct stabilities of aldehyde and radiation-induced DPCs. Nucleic acids research 2012, 40(18):e143. 
24. Xie MZ, Shoulkamy MI, Salem AMH, Oba S, Goda M, Nakano T, Ide H: Aldehydes with high and low toxicities inactivate cells by damaging distinct cellular targets. Mutation Research/fundamental \& Molecular Mechanisms of Mutagenesis 2016, 786:41-51.

25. Jr BR, Bellani M, Liu Y, Seidman MM: Fanconi Anemia: A DNA repair disorder characterized by accelerated decline of the hematopoietic stem cell compartment and other features of aging. Ageing Research Reviews 2016, 17(16).

26. Esterbauer $\mathrm{H}$, Jürgens $\mathrm{G}$, Quehenberger $\mathrm{O}$, Koller $\mathrm{E}$ : Autoxidation of human low density lipoprotein: loss of polyunsaturated fatty acids and vitamin $E$ and generation of aldehydes. Journal of Lipid Research 1987, 28(5):495.

27. Thornalley PJ, Langborg A, Minhas HS: Formation of glyoxal, methylglyoxal and 3-deoxyglucosone in the glycation of proteins by glucose. Biochemical Journal 1999, 344(1):109-116.

28. Jovanovic O, Vazdar M, Pohl EE: Lipid Membranes as a Target for Reactive Aldehyde Action. Biophysical Journal 2018, 114(3):258a.

29. Gallelli C, Calcagnini S, Romano A, Koczwara J, Ceglia MD, Dante D, Villani R, Giudetti A, Cassano T, Gaetani S: Modulation of the Oxidative Stress and Lipid Peroxidation by Endocannabinoids and Their Lipid Analogues. Antioxidants 2018, 7(7):93-.

30. Zhu L, Yang YZ, Guan HY, Cheng SM, Jin YY, Tan WG, Wu QF, Liu XL, Zhao MG, Lu ZH et al: Trends in drug-resistant tuberculosis after the implementation of the DOTS strategy in Shenzhen, China, 2000-2013. The international journal of tuberculosis and lung disease : the official journal of the International Union against Tuberculosis and Lung Disease 2017, 21(7):759-765.

31. Nmo A, Luna C, Madruga MS, Estévez M: Antioxidant and pro-oxidant actions of resveratrol on human serum albumin in the presence of toxic diabetes metabolites: Glyoxal and methyl-Glyoxal. Biochimica Et Biophysica Acta 2018:S0304416518301697-.

32. Perone F, Lembo G: Thioredoxin-1: a cardioprotector against stress. Cardiovascular research 2020, 116(10):1654-1655.

33. Dafre AL, Goldberg J, Wang T, Spiegel DA, Maher P: Methylglyoxal, the foe and friend of glyoxalase and Trx/TrxR systems in $\mathrm{HT} 22$ nerve cells. Free Radical Biology \& Medicine 2015, 89:8-19.

34. Park YS, Kim J, Misonou Y, Takamiya R, Takahashi M, Freeman MR, Taniguchi N: Acrolein induces cyclooxygenase-2 and prostaglandin production in human umbilical vein endothelial cells: roles of p38 MAP kinase. Arteriosclerosis Thrombosis \& Vascular Biology 2007, 27(6):1319.

35. Verheij M, Bose R, Lin XH, Yao B, Jarvis WD, Grant S, Birrer MJ, Szabo E, Zon LI, Kyriakis JM: Requirement for ceramide-initiated SAPK/JNK signalling in stress-induced apoptosis. Nature 1996, 380(6569):75-79.

36. Li FH, Han N, Wang Y, Xu Q: Gadd45a knockdown alleviates oxidative stress through suppressing the p38 MAPK signaling pathway in the pathogenesis of preeclampsia. Placenta 2018, 65:20.

37. Gong W, Zhu G, Li J, Yang X: LncRNA MALAT1 promotes the apoptosis and oxidative stress of human lens epithelial cells via p38MAPK pathway in diabetic cataract. Diabetes Res Clin Pract 2018:S0168822717318247-. 
A:

580

581

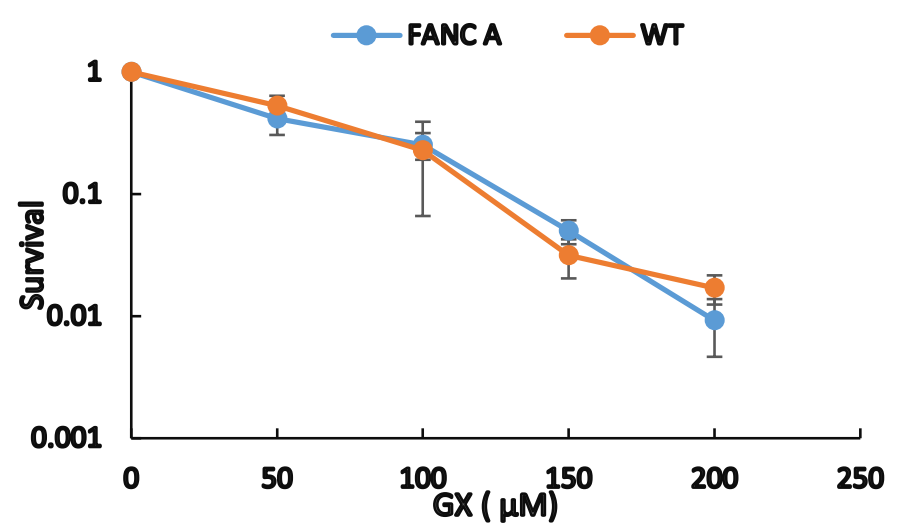

582

B:

583
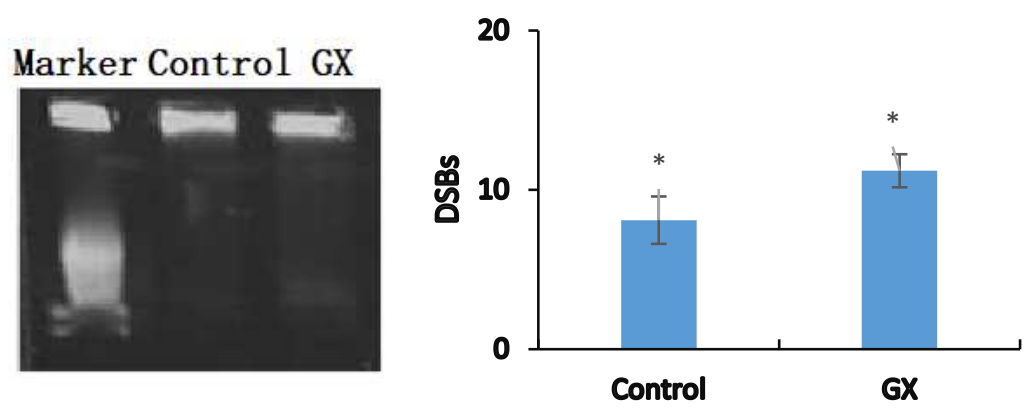

584

585

C:

586

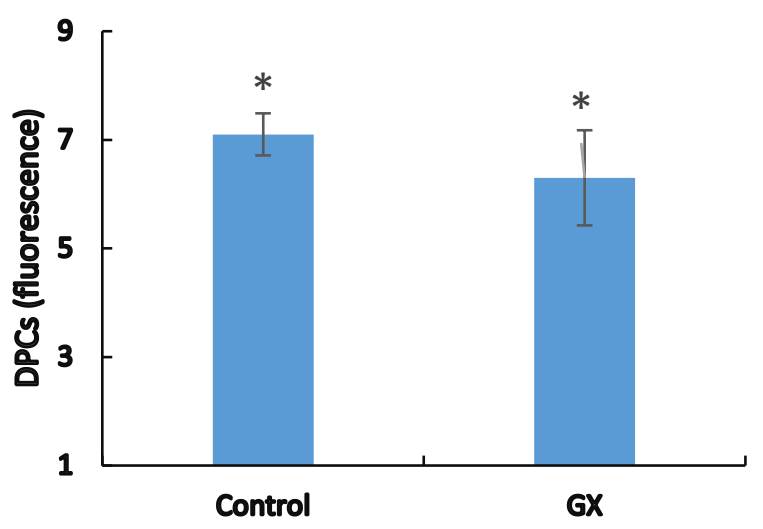


591 Fig 1. Analysis of DNA damage induced by glyoxal (GX) based on human aortic endothelial cells (HAECs) deficient in the FANC pathway. (A) HAECs were treated

593 with a range of concentrations $(50,100,150,200 \mu \mathrm{M})$ of $\mathrm{GX}$ for 8 days, and their 594 survival was determined. Drug lethal dose $\left(\mathrm{LD}_{90}\right)$ values were confirmed from 595 survival curves and are indicated by an arrow. (B) Double strand break (DSB) 596 induction. DSBs were detected using static-field gel electrophoresis after treatment 597 with the fraction of DNA released relative to the total DNA. (C) Analysis of 598 DNA-protein crosslinks (DPCs). $p<0.05$ indicates statistical significance.

599 A:

600

601

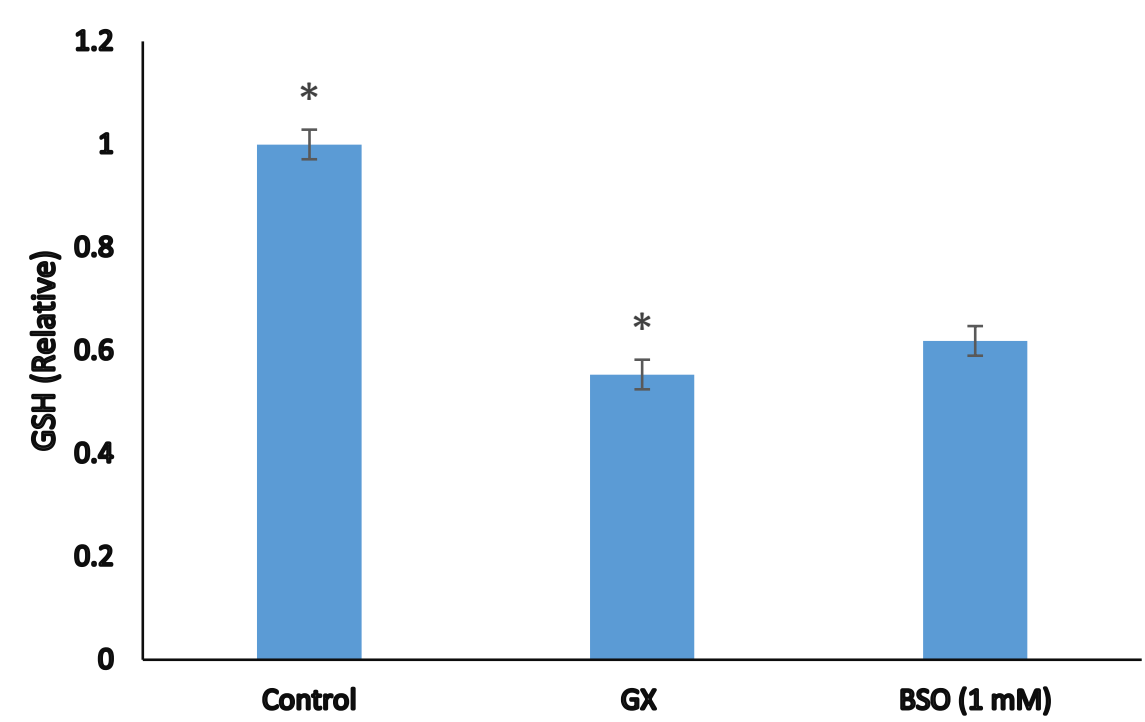

602

B:

603 


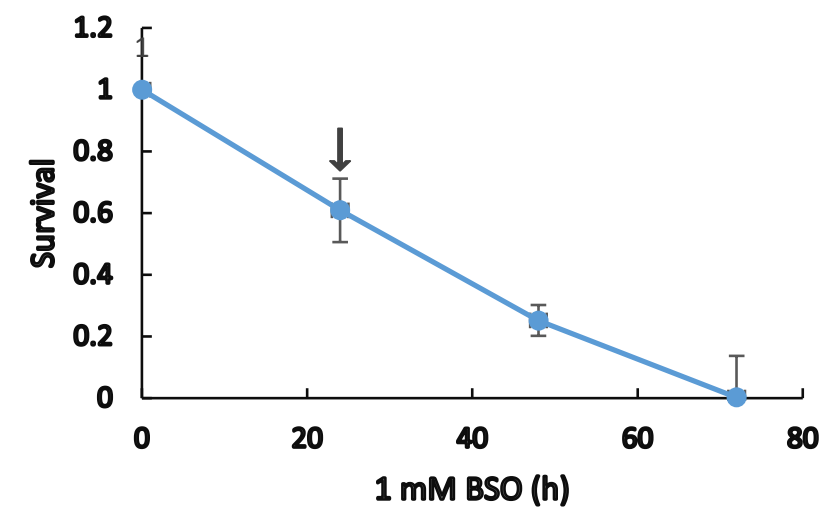

604

605

606

607

608

609

610

611

612

613

A:

614

B:

Fig. 2. Effect of Glyoxal (GX) on Intracellular Glutathione (GSH).

Fig. 2. Effect of glyoxal (GX) on intracellular glutathione (GSH). (A) Data are the means \pm standard deviations of three separate tests. Statistically significant differences are indicated by an asterisk, $p<0.05$ indicates statistical significance. (B) Buthionine sulfoximine (BSO; $1 \mathrm{mM}$ ) was used to treat human aortic endothelial cells (HAECs) for different times, and cell survival was subsequently determined.

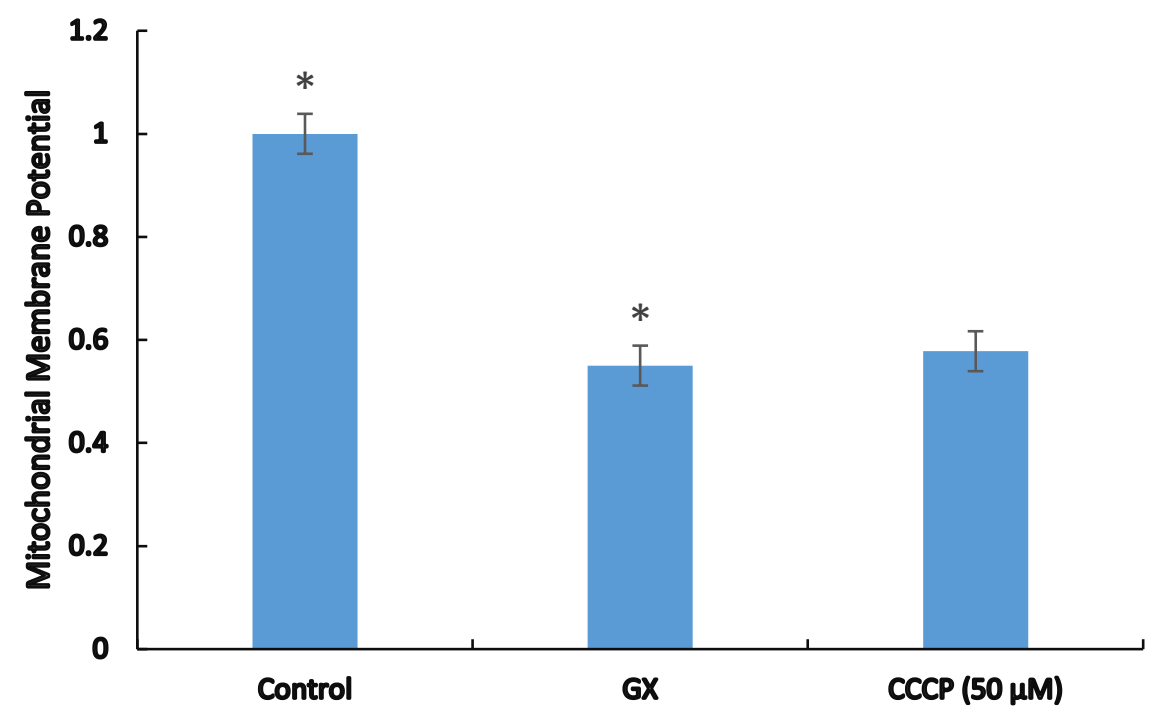




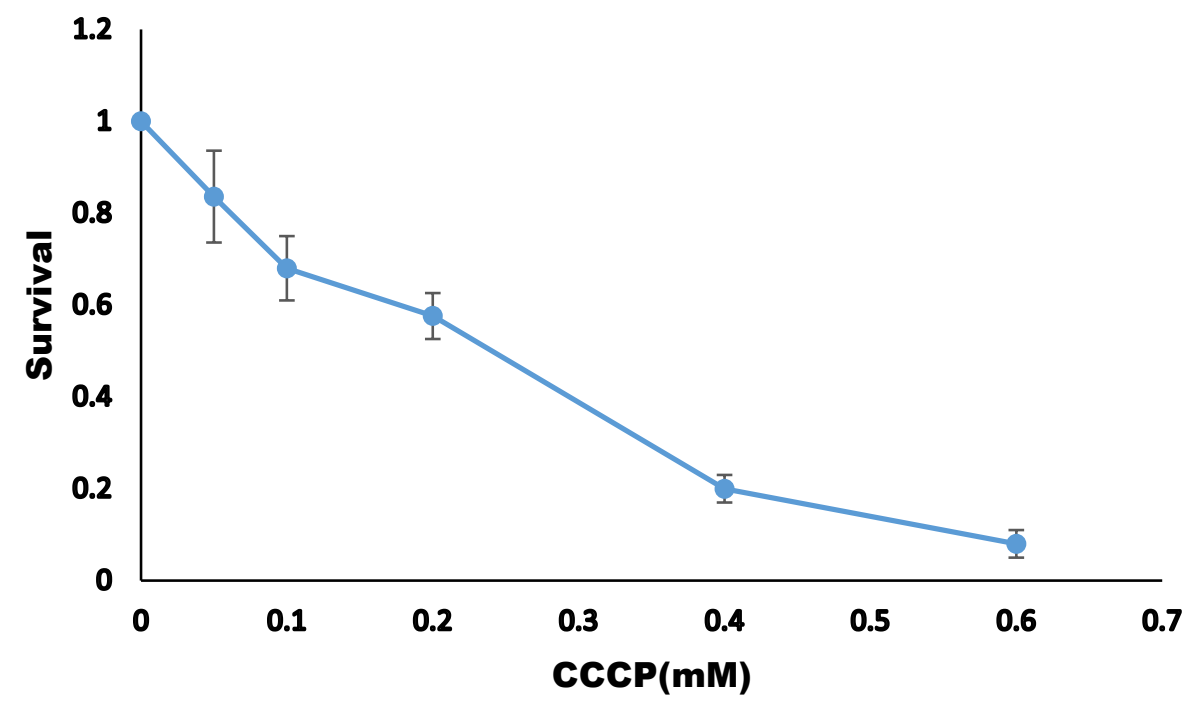

616

Fig. 3. Effect of Glyoxal (GX) on the Mitochondrial Membrane Potential.

Fig. 3. Effect of Glyoxal (GX) on the mitochondrial membrane potential. (A) Human aortic endothelial cells (HAECs) were treated with GX. Statistically significant differences are indicated by an asterisk, $p<0.05$ indicates statistical significance. . (B) Survival of cyanide $m$-chlorophenylhydrazone (CCCP)-treated HAECs.

$$
\text { IAA IAA/IAM IAM Control GX Auro }
$$

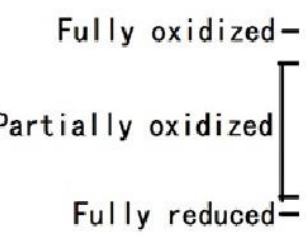


629

630

631

632

633

634

635

636

637 638 human aortic endothelial cells (HAECs).

B:
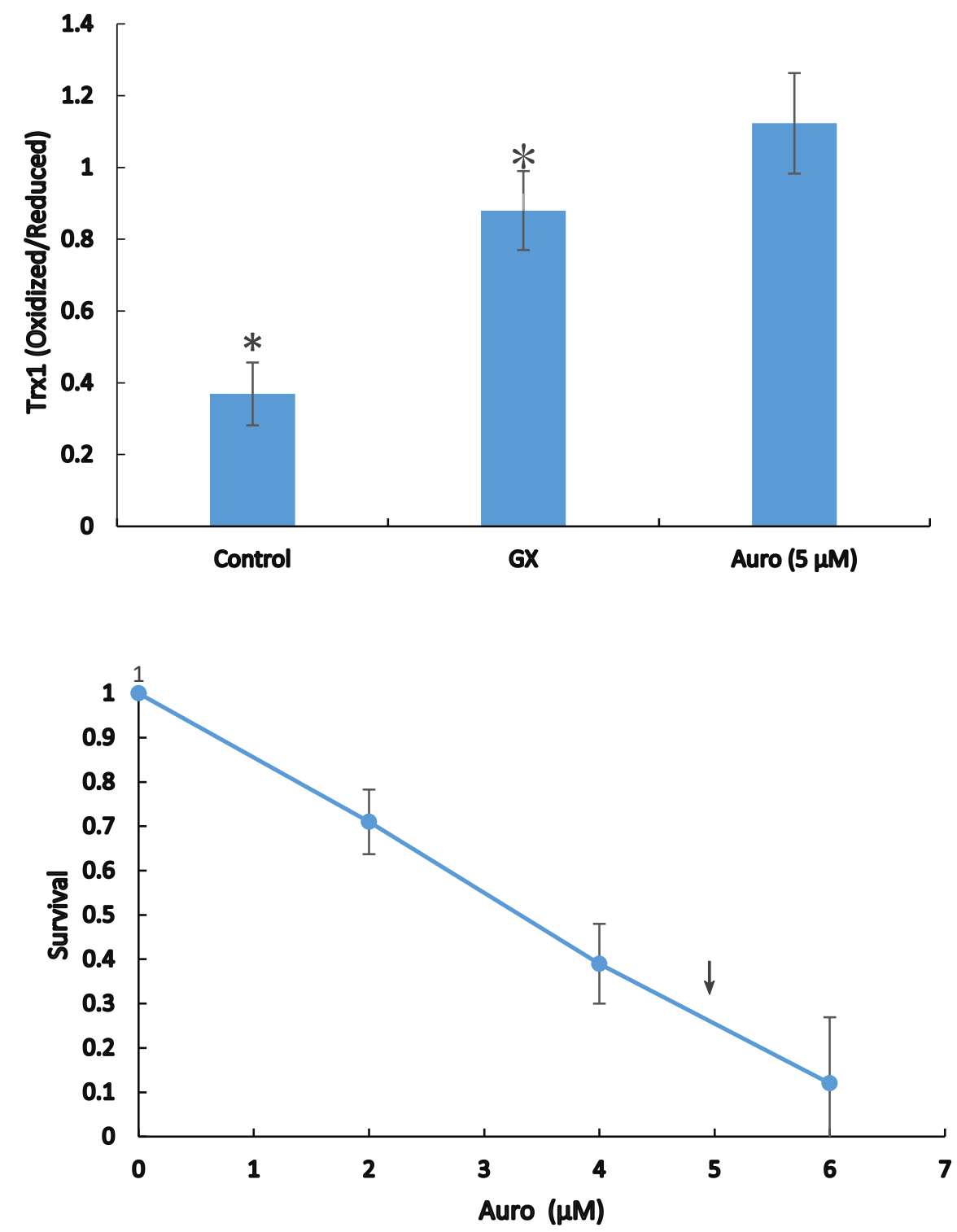

Fig. 4. Redox state of Trx1. (A) Effects of glyoxal (GX) on the redox state of Trx1.

Trx 1 was either in a completely reduced state (iodoacetic acid (IAA) band) or completely oxidized state (iodoacetamide (IAM) band). Statistical differences are indicated by an asterisk, $p<0.05$ indicates statistical significance.(B) Survival of

639 
640

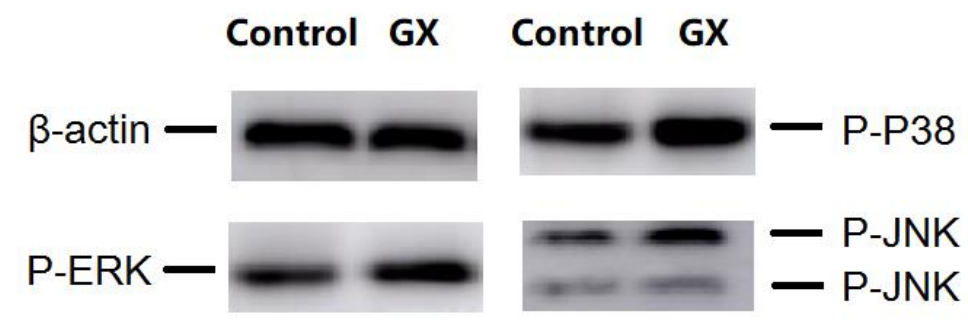

641

642

643

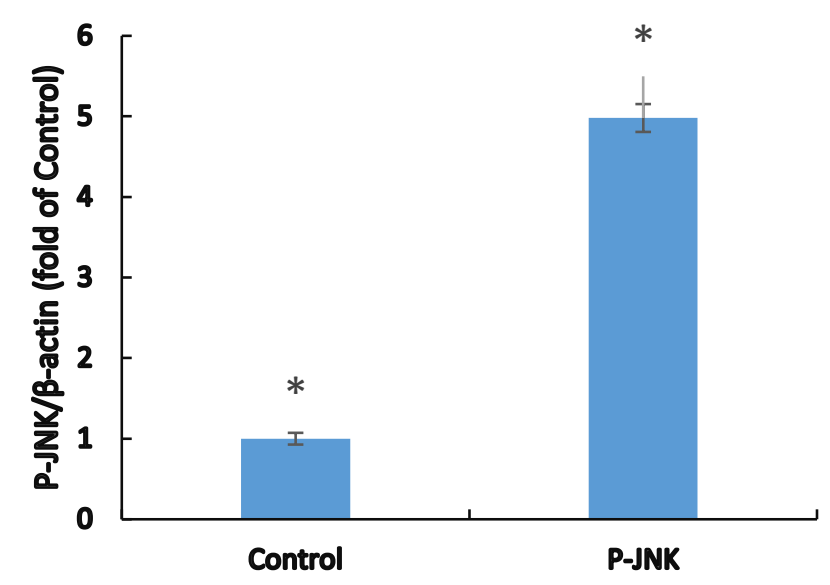

644

645

646

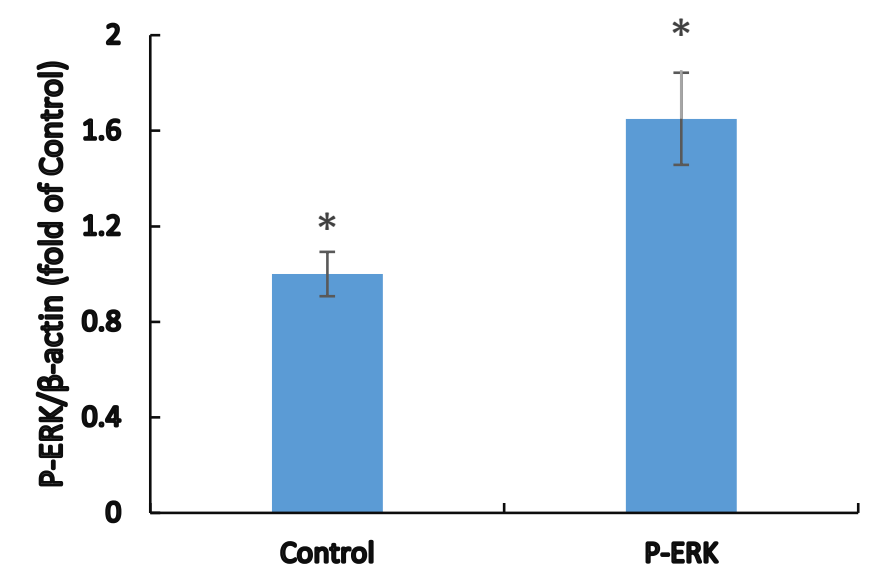

647 
648

649

650

651

652

653 Fig. 5. Effect of glyoxal (GX) on MAP kinase pathways. Statistical differences are 654 indicated by an asterisk $p<0.05$ indicates statistical significance.

Fig. 5 Effect of Glyoxal (GX) on MAP Kinase Pathways.

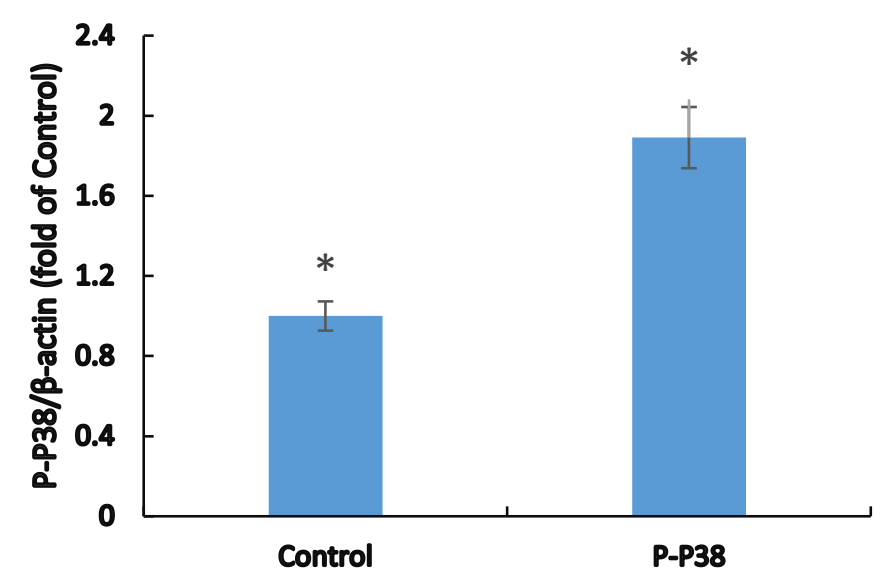

655 


\section{Figures}

A:

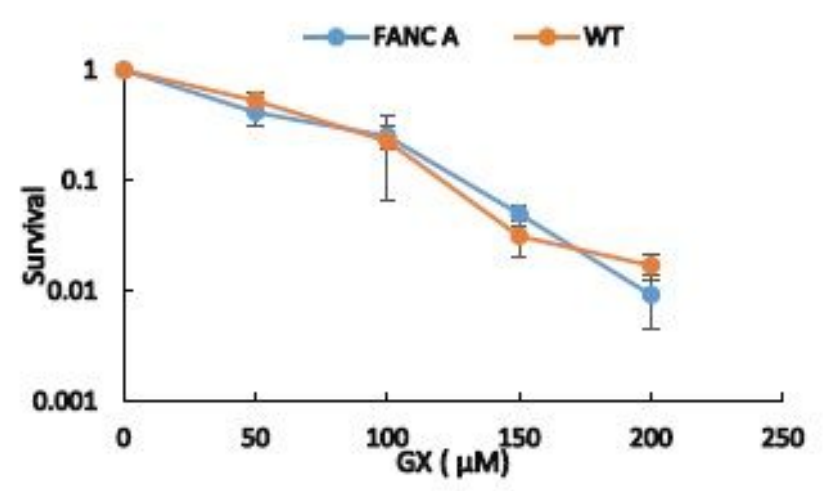

B:
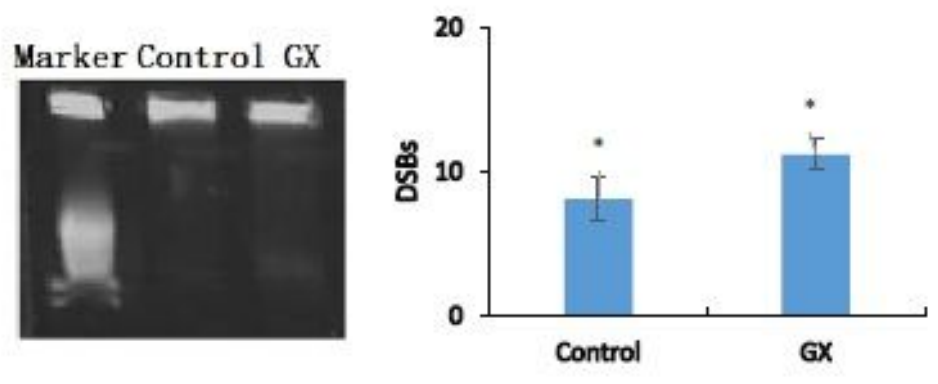

C:

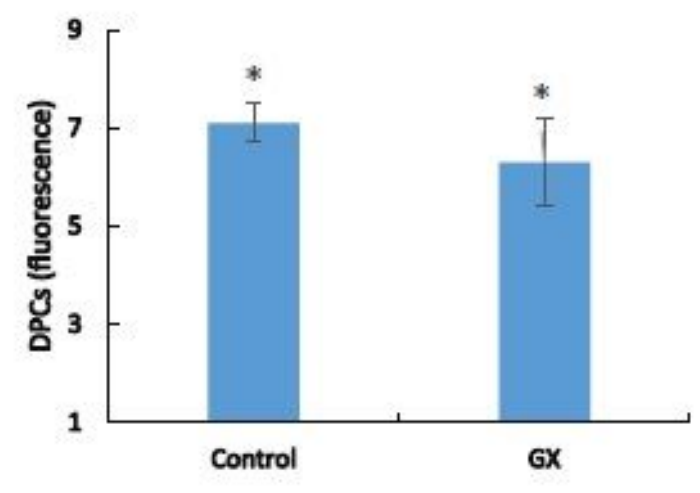

\section{Figure 1}

Analysis of DNA Damage Induced by Glyoxal (GX) in Human Aortic Endothelial Cells (HAECs) Deficient in the FANC Pathway. Analysis of DNA damage induced by glyoxal (GX) based on human aortic endothelial cells (HAECs) deficient in the FANC pathway. (A) HAECs were treated with a range of concentrations (50, 
$100,150,200 \mu \mathrm{M}$ ) of $\mathrm{GX}$ for 8 days, and their survival was determined. Drug lethal dose (LD 90 values were confirmed from survival curves and are indicated by an arrow. (B) Double strand break (DSB) induction. DSBs were detected using static field gel electrophoresis after treatment with the fraction of DNA released relative to the total DNA. (C) Analysis of DNA protein crosslinks (DPCs). $p<0.05$ indicates statistical significance.

\section{A:}

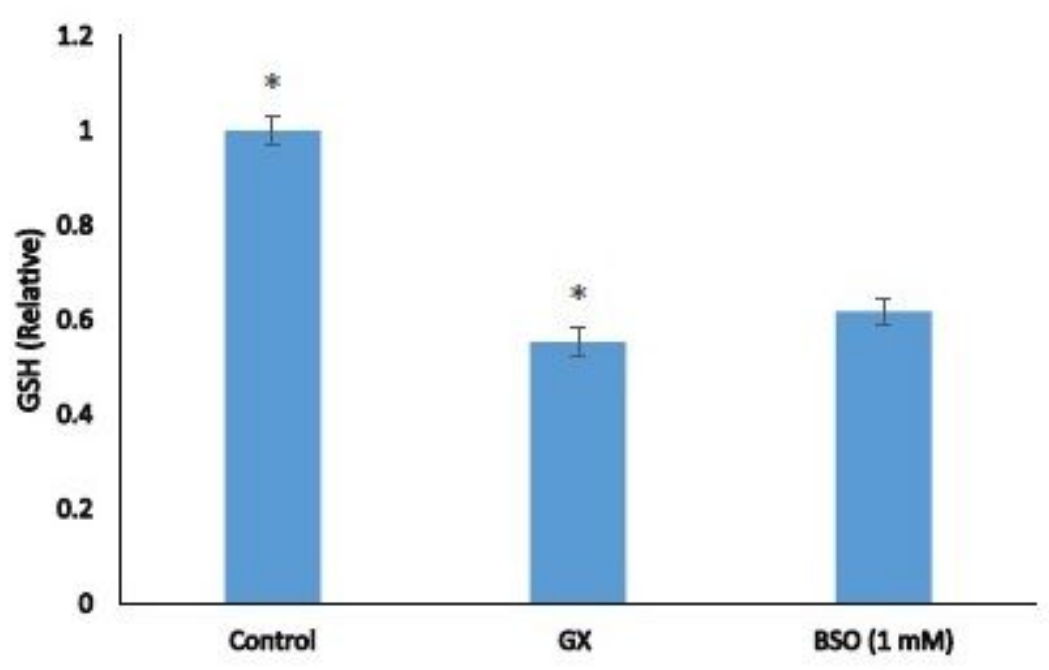

B:

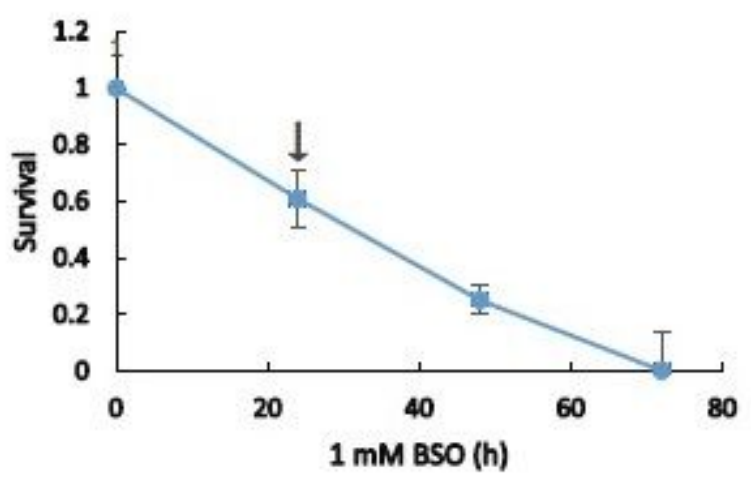

Figure 2

Effect of Glyoxal (GX) on Intracellular Glutathione (GSH). Effect of glyoxal ( GX) on intracellular glutathione (GSH). (A) Data are the means \pm standard deviations of three separat e tests. Statistically significant differences are indicated by an asterisk, $p<0.05$ indicates statistical significance. (B) Buthionine sulfoximine (BSO; $1 \mathrm{mM}$ ) was used to treat human aortic endothelial cells (HAECs) for different times, and cell survival was subsequently determined. 
A:

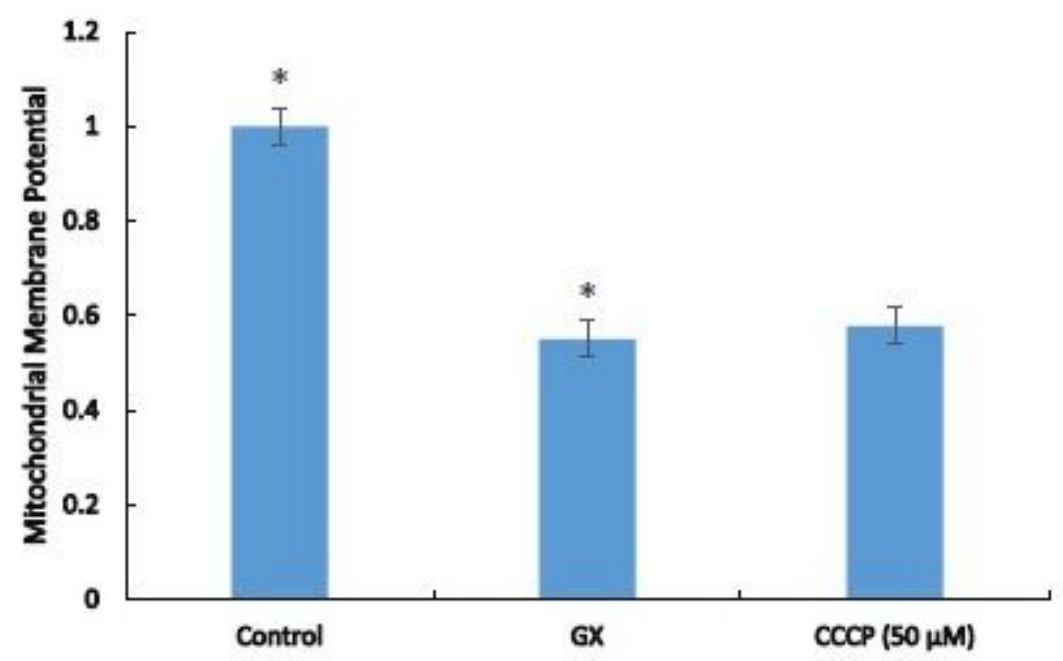

B:

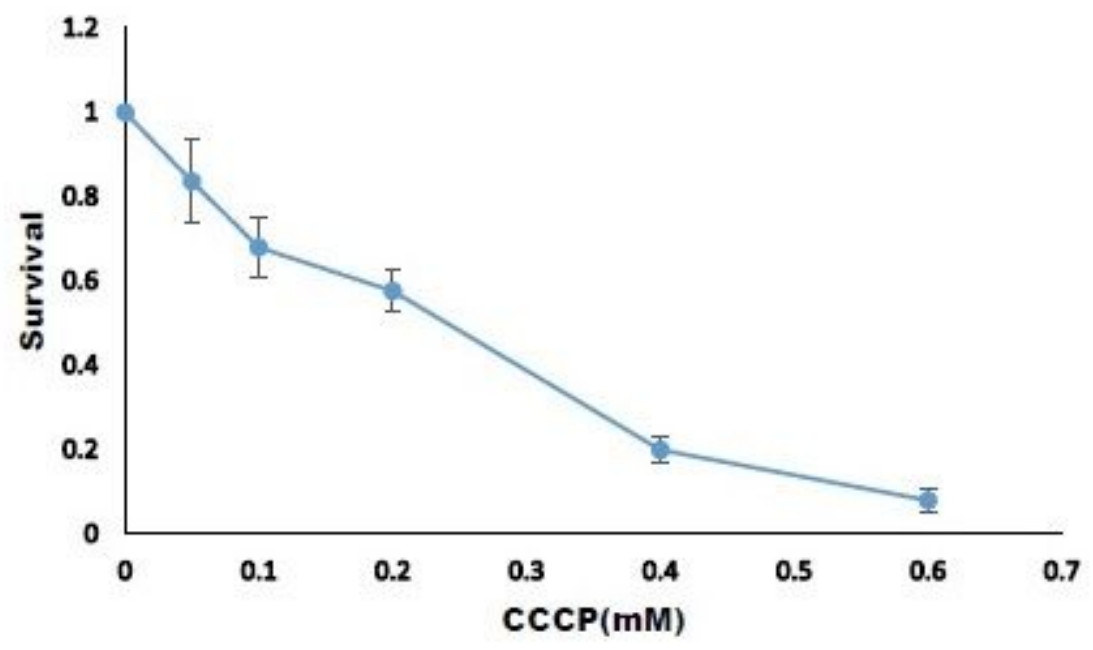

Figure 3

Effect of Glyoxal (GX) on the Mitochondrial Membrane Potential. Effect of Glyoxal ( GX) on the mitochondrial membrane potential. (A) Human aortic endothelial cells (HAECs) were treated with GX Sta tistically significant differences are indicated by an asterisk, $p<0.05$ indicates statistical significance. . (B) Survival of cyanide $m$ chlorophenylhydrazone (CCCP) treated HAECs. 
A:

$$
\text { IAA IAA/IAM IAM Control GX Auro }
$$
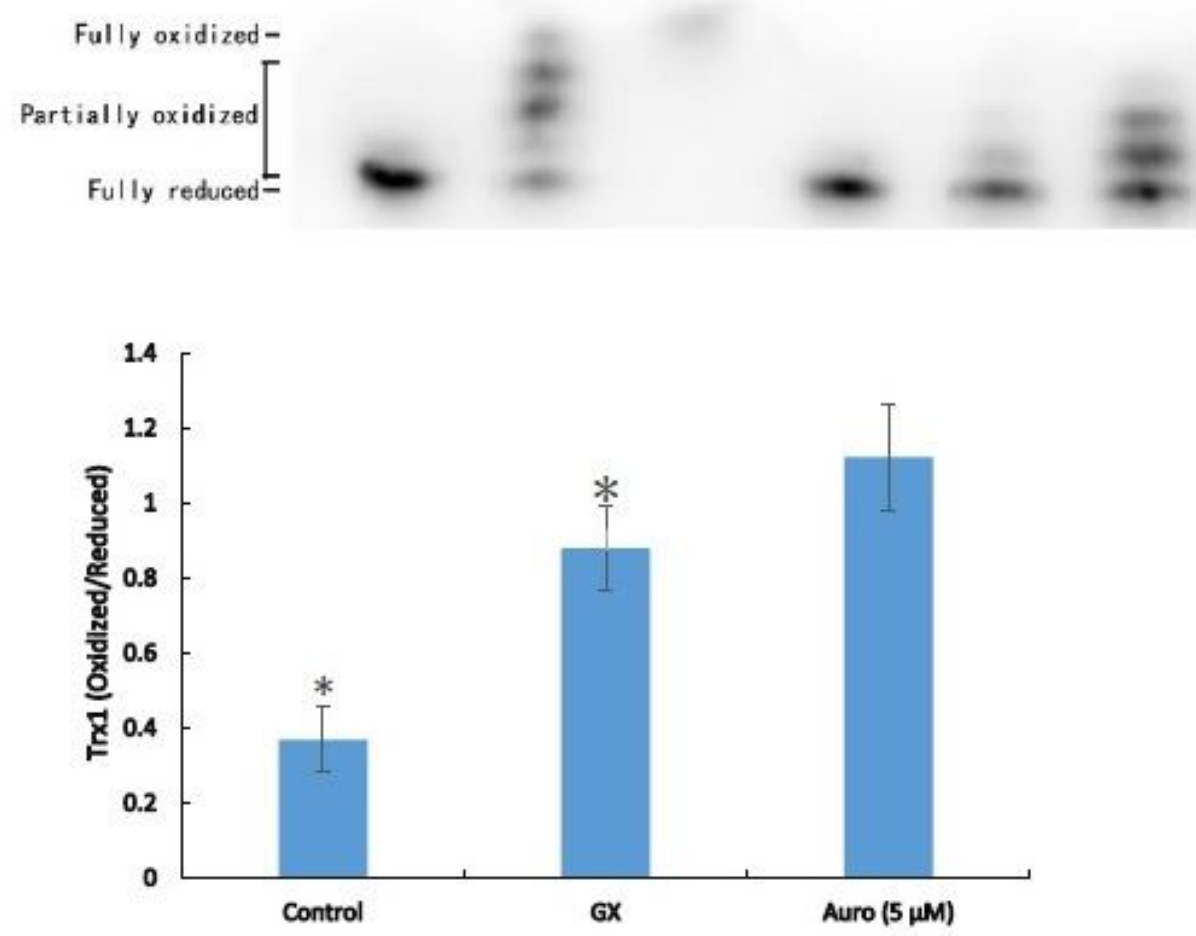

B:

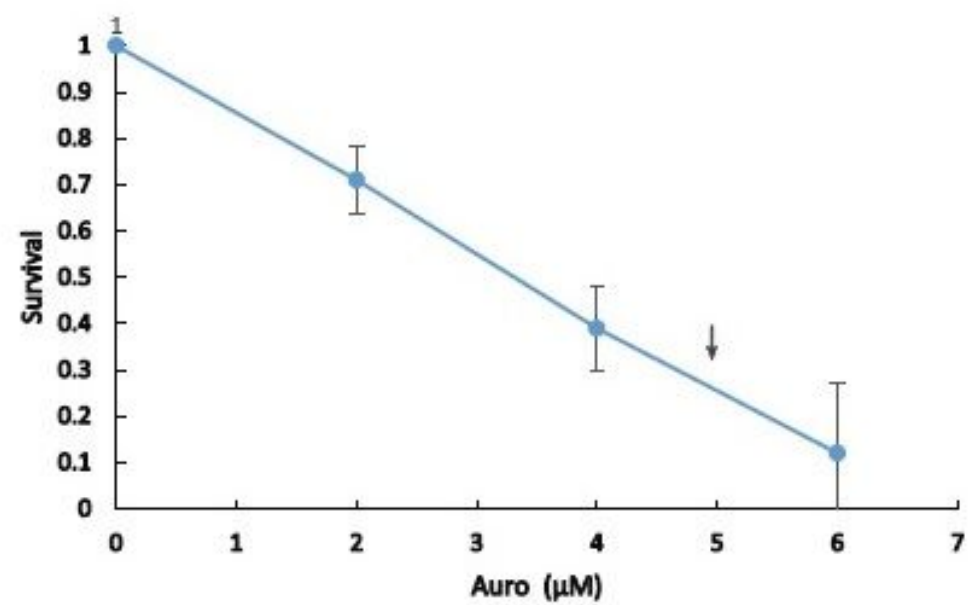

\section{Figure 4}

Redox state of Trx1. (A) Effects of glyoxal ( GX) on the redox state of Trx1. Trx1 was either in a completely reduced state (iodoacetic acid (IAA) band) or completely oxidized state (iodoacetamide (IAM) band). Statistical differences are indicated by an asterisk, $\mathrm{p}<0.05$ indicates statistical significa nce.(B) Survival of human aortic endothelial cells (HAECs). 

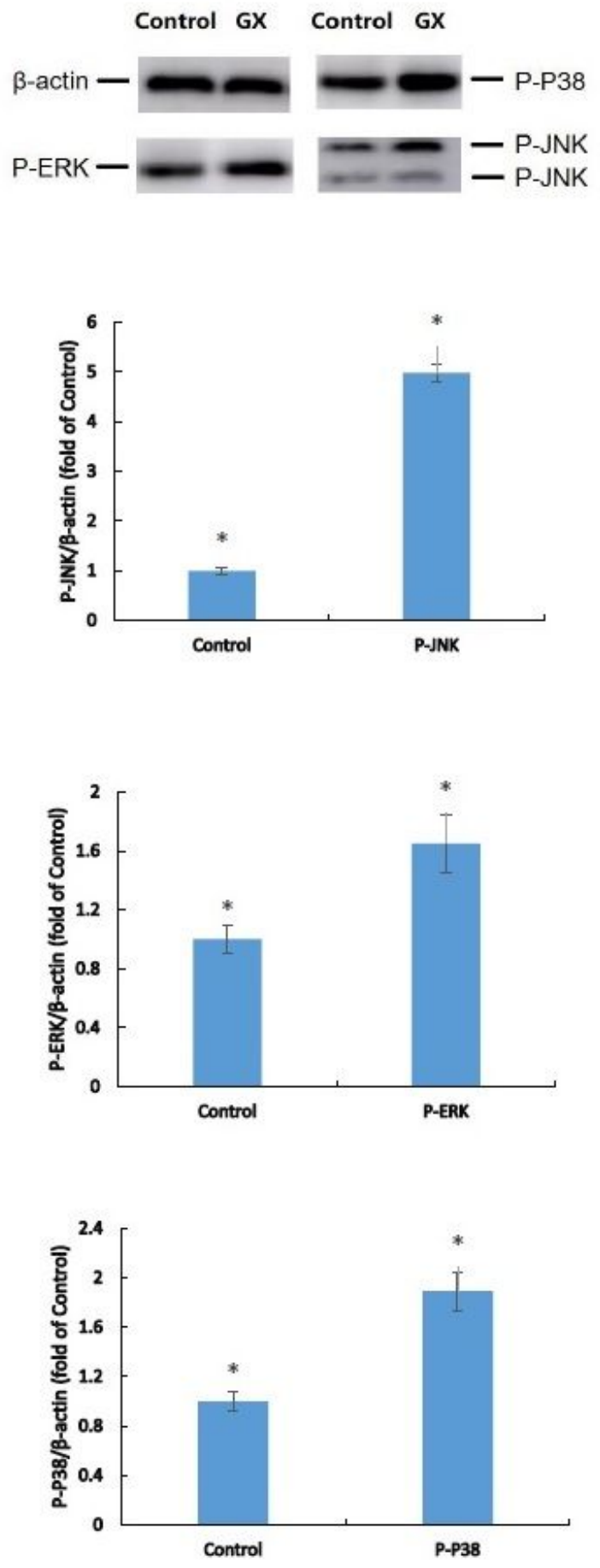

Figure 5

Effect of glyoxal (GX) on MAP kinase pathways. Statistical differences are indicated by an asterisk $\mathrm{p}<$ 0.05 indicates statistical significance. 